\title{
Crystal Structure, Thermal Behavior and Vibrational Spectra of 4,4'Diamoniumdiphenylmethan Sulfate Hydrate
}

\author{
Takoua Ben Issa ${ }^{1,2 *}$, Latifa Benhamada ${ }^{1}$ \\ ${ }^{1}$ Laboratory of Energy and Materials (LabEM-LR11ES34), High School of Sciences and Technologies of Hammam Sousse, \\ Hammam Sousse, Tunisia \\ ${ }^{2}$ Facultyof sciences of Monastir, Hammam Sousse, Tunisia \\ Email: ^benissatakoua@gmail.com
}

How to cite this paper: Issa, T.B. and Benhamada, L. (2017) Crystal Structure, Thermal Behavior and Vibrational Spectra of 4,4'Diamoniumdiphenylmethan Sulfate Hydrate. Open Journal of Inorganic Chemistry, 7, 61-73.

https://doi.org/10.4236/ojic.2017.72004

Received: March 8, 2017

Accepted: April 27, 2017

Published: April 30, 2017

Copyright (ङ 2017 by authors and Scientific Research Publishing Inc. This work is licensed under the Creative Commons Attribution International License (CC BY 4.0). http://creativecommons.org/licenses/by/4.0/

\begin{abstract}
Single crystals of the 4,4'-diamoniumdiphenylmethan sulfate hydrate, denoted DDPS, were grown by slow evaporation solution technique at room temperature. The compound was characterized by single crystal X-ray diffraction, IR and thermal analysis (TG-DTA). It crystallizes in the monoclinic system (space group C2/c) with the following unit cell dimensions: $a=17.7635(10) \AA, b$ $=9.3796(10) \AA, c=27.5676(10) \AA, \beta=97.367(2)^{\circ}, V=4555.2(6) \AA . T h e$ structure was solved by the direct method and refined to final $\mathrm{R}$ value of 0.0472 for 2108 independent reflections. The anions are hydrogen bonded to each other, forming clusters $\left[\mathrm{HS}_{2} \mathrm{O}_{8}\right]^{3-}$ parallel to the plan $(\mathrm{a}, \mathrm{b})$. The water molecules connect these clusters via $\mathrm{O}-\mathrm{H} \cdots \mathrm{O}$ hydrogen bonds. The organic cations are attached to the clusters through $\mathrm{N}-\mathrm{H} \cdots \mathrm{O}$ hydrogen bonds, forming an infinite three-dimensional network.
\end{abstract}

\section{Keywords}

Organic Sulfate, Crystalline Structure, Vibrational Spectra, Thermal Behavior, Differential Thermal Analysis

\section{Introduction}

The chemistry of hybrid materials has received an important growth in last two decades; it was an impressive area of research for many investigations in different field of sciences [1] [2] [3]. In fact, "pillared layer" materials and threedimensional frameworks are formed involving the sulfates ligands which pro- 
mote the formation of alternating organic and inorganic layers [4]. Not only the morphologies or the length of sulfate groupments can give this chemistry its important feature; but also the chemical identity of the organic group can profoundly influence the whole structure of these compounds [5]. Presently, various syntheses of organically cation-templated sulfates crystals were the subject of many investigations which have been of great benefit in various fields of sciences [6] [7] [8]. It is worthy to note that, in general, the observed sulfate anions are, basically $\left[\mathrm{HSO}_{4}\right]^{-}$or $\left[\mathrm{SO}_{4}\right]^{2-}$. The cohesion forces in these hybrid compounds are dominated by electrostatic interactions, Vander Waals contacts, and hydrogen bonds $(\mathrm{O}-\mathrm{H} \cdots \mathrm{O}$ and $\mathrm{N}-\mathrm{H} \cdots \mathrm{O})$. These hydrogen bonds play an important role in the mechanism of association of molecules that either biological or not [9].

The title compound (DDPS) is an additional example for illustrating the templating effect of aromatic ammonium molecules on sulfate. In addition, structural considerations resulting from crystallographic studies, some organic sulfates exhibit non-linear optical properties [10], or phase transitions [11]. The present work continues a series of investigations into the factors influencing the dimensions of sulfate anion-organic cation interaction. We report here the chemical preparation, crystallographic features, thermal behavior, and IR analysis of a new organic sulfate, $\left(\mathrm{C}_{13} \mathrm{H}_{16} \mathrm{~N}_{2}\right)_{1.5} \mathrm{HSO}_{4} \mathrm{SO}_{4} \cdot \mathrm{H}_{1.5} \mathrm{O}$.

\section{Experimental}

\subsection{Synthesis}

By slow evaporation single crystals of the studied compound were obtained from a solution of 4,4'diaminodiphenylmethan [Sigma-Aldrich] and sulfuric acid (98 wt\% from Fluka) as obtained from commercial sources without further purification. A solution of 4,4'-diaminodiphenylmethan $(1.98 \mathrm{~g}, 0.01 \mathrm{~mol})$ in $200 \mathrm{~mL}$ of water was added to a solution of sulfuric acid. The resulting solution was filtered through paper and left at room temperature. After several days, transparent and good single crystals were produced, which were filtered and air dried.

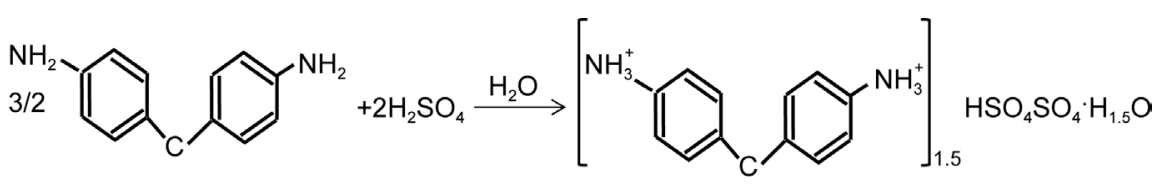

\subsection{Characterization}

\subsubsection{X-Ray Single Crystal Structure Determination}

The intensity data collection was performed using an Enraf-Noniusdiffractometer and monochromated Mo radiation $(\lambda=0.71073 \AA)$. Pertinent details of the crystal structure of $\left(\mathrm{C}_{13} \mathrm{H}_{16} \mathrm{~N}_{2}\right)_{1.5} \mathrm{HSO}_{4} \mathrm{SO}_{4} \cdot \mathrm{H}_{1.5} \mathrm{O}$ are listed. The strategy used for the structure determination and its final results are gathered in Table 1. The structure was solved with a direct method, from the SHELXS-97 programs, which permitted the location of the $\mathrm{HSO}_{4}$ and $\mathrm{SO}_{4}$ groups. The remaining nonhydrogen atoms were located by the successive difference. 
Table 1. Crystal structure data for $\left(\mathrm{C}_{13} \mathrm{H}_{16} \mathrm{~N}_{2}\right)_{1.5} \mathrm{HSO}_{4} \mathrm{SO}_{4} \cdot \mathrm{H}_{1.5} \mathrm{O}$.

\begin{tabular}{|c|c|}
\hline Compound & $\left(\mathrm{C}_{13} \mathrm{H}_{16} \mathrm{~N}_{2}\right)_{1.5} \mathrm{HSO}_{4} \mathrm{SO}_{4} \cdot \mathrm{H}_{1.5} \mathrm{O}$ \\
\hline Color/shape & Colorless/prismatic \\
\hline Formula weight & $511.06 \mathrm{~g} / \mathrm{mol}$ \\
\hline Crystal system & monoclinic \\
\hline Space group & $\mathrm{C} 2 / \mathrm{c}(15)$ \\
\hline Temperature, $\mathrm{K}$ & $293(2)$ \\
\hline \multicolumn{2}{|l|}{ Unit cell dimensions } \\
\hline \multicolumn{2}{|l|}{$a=17.7635(10) \AA$} \\
\hline $\mathrm{b}=9.3796(10) \AA$ & $\beta=97.37(2)$ \\
\hline \multicolumn{2}{|l|}{$c=27.5676(10) \AA$} \\
\hline Cell volume, Å3 & $4555.2(6)$ \\
\hline $\mathrm{Z}$ & 8 \\
\hline Density (calculated), $\mathrm{g} / \mathrm{cm}^{3}$ & 1.490 \\
\hline Absorption coefficient, $\mathrm{mm}^{-1}$ & 0.291 \\
\hline diffraction measurement device & Enraf-Nonius CAD4 \\
\hline Radiation, graphite monochr & $\operatorname{MoK} \alpha(\lambda=0.71073 \AA)$ \\
\hline Max. crystal dimensions, $\mathrm{mm}$ & $0.15 \times 0.2 \times 0.3$ \\
\hline$\theta$ range & $2-25.00$ \\
\hline Range of $h, k$ & $-16 \leq h \leq 16,-2 \leq k \leq 9,0 \leq 1 \leq 26$ \\
\hline Number of independent ref. & 2108 \\
\hline Unique reflexions included: $(\mathrm{I}>2 \sigma)$ & 1807 \\
\hline Computer programs & SHELX-97 [9] \\
\hline Data reductions programs & Denzo $[10]$ \\
\hline Refined parameters & 409 \\
\hline Goodness of fit on F2 & 1.00 \\
\hline $\mathrm{R}$ & 0.0472 \\
\hline $\mathrm{Rw}$ & 0.1265 \\
\hline Extinction coefficient & $0.0002(3)$ \\
\hline$\Delta \rho \min . / \Delta \rho \max .(\mathrm{e} / \AA ̊ \AA)$ & $-0.480 / 0.311$ \\
\hline Langest shift error $\mathrm{max} / \mathrm{min}$ & $0.0002 / 0.000$ \\
\hline
\end{tabular}

Fourier maps using the SHELXL-97 programs [12]. In the final least-squares refinement of atomic parameters with isotropic thermal factors of the hydrogen atoms, $\mathrm{R}$ decreased to $4.72 \%(\mathrm{Rw}=12.60 \%)$ for DDPS. Full crystallographic information related the crystal structure has been deposited at the CCDC as CIF file, No. CCDC 1540491. Copies of this information may be obtained free of charge from the director, CCDC, 12 Union Road, Cambridge, CB2 1EZ, UK (fax: +44 1223 033; deposit@ccdc.cam.ac.uk or www.http://wwwccdc.cam.ac.uk). 


\subsubsection{Infrared Spectroscopy}

IR spectrum of DDPS was recorded at room temperature with a Biored FTS 6000 FTIR spectrometer over the wave number range of $4000-400 \mathrm{~cm}^{-1}$ with a resolution of about $4 \mathrm{~cm}^{-1}$. Thin, transparent pellet was made by compacting an intimate mixture obtained by shaking $2 \mathrm{mg}$ of the samples in $100 \mathrm{mg}$ of $\mathrm{KBr}$.

\subsubsection{Thermal Analysis}

Setaram TG-DTA92 thermoanalyzer was used to perform thermal analysis on samples of DDPS. The TG-DTA thermograms were obtained with $21.5 \mathrm{mg}$. Samples were placed in an open platinum crucible and heated in air with $5^{\circ} \mathrm{C} /$ min heating rate; an empty crucible was used as reference.

\section{Results and Discussion}

\subsection{DDPS Structure Description}

The crystal of the title compound is built up from 4,4'-diamoniumdiphenylmethan cations, two types of sulfate anions with different ionization state, i.e. $\left[\mathrm{HSO}_{4}\right]^{-}$monoanions and $\left[\mathrm{SO}_{4}\right]^{2-}$ dianions, and from water molecules. Figure 1 showed that the asymmetric unit of $\left(\mathrm{C}_{13} \mathrm{H}_{16} \mathrm{~N}_{2}\right)_{1.5} \mathrm{HSO}_{4} \mathrm{SO}_{4} \cdot \mathrm{H}_{1.5} \mathrm{O}$ was formed by two crystallographically different cations, two independent anions and one water molecule. The main geometrical features of different entities are indicated in Table 2.

A view of the structure projected along the $\boldsymbol{b}$ axis is reported in Figure 2. The atomic arrangement of the structure of the DDPS was described by a three-
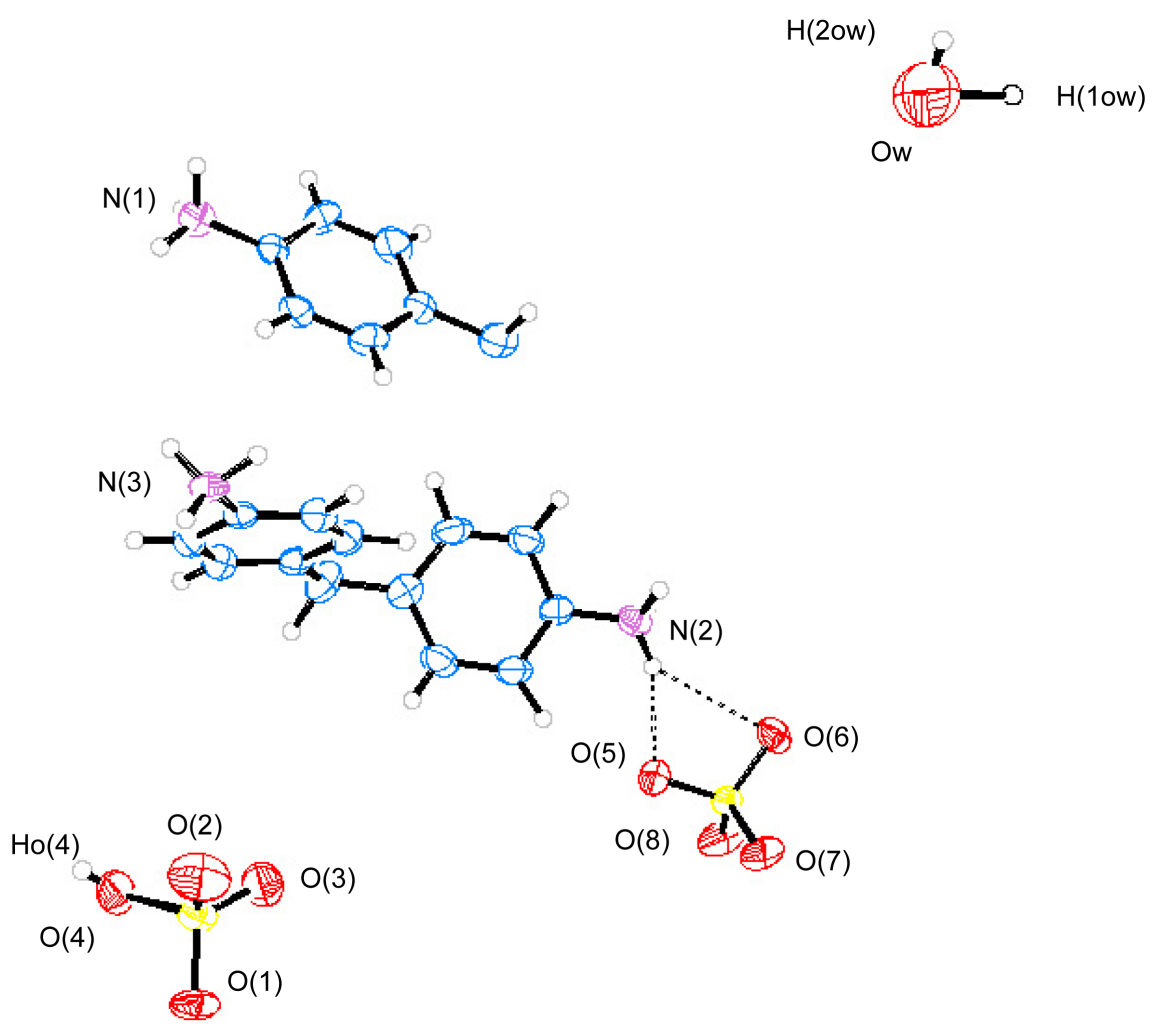

Figure 1. Ortep drawing of the asymmetric unit of DDPS. 
Table 2. Main interatomic distances $(\AA)$ and bond angles $\left(^{\circ}\right)$ for $\left(\mathrm{C}_{13} \mathrm{H}_{16} \mathrm{~N}_{2}\right)_{1.5} \mathrm{HSO}_{4}$ $\mathrm{SO}_{4} \cdot \mathrm{H}_{1.5} \mathrm{O}$.

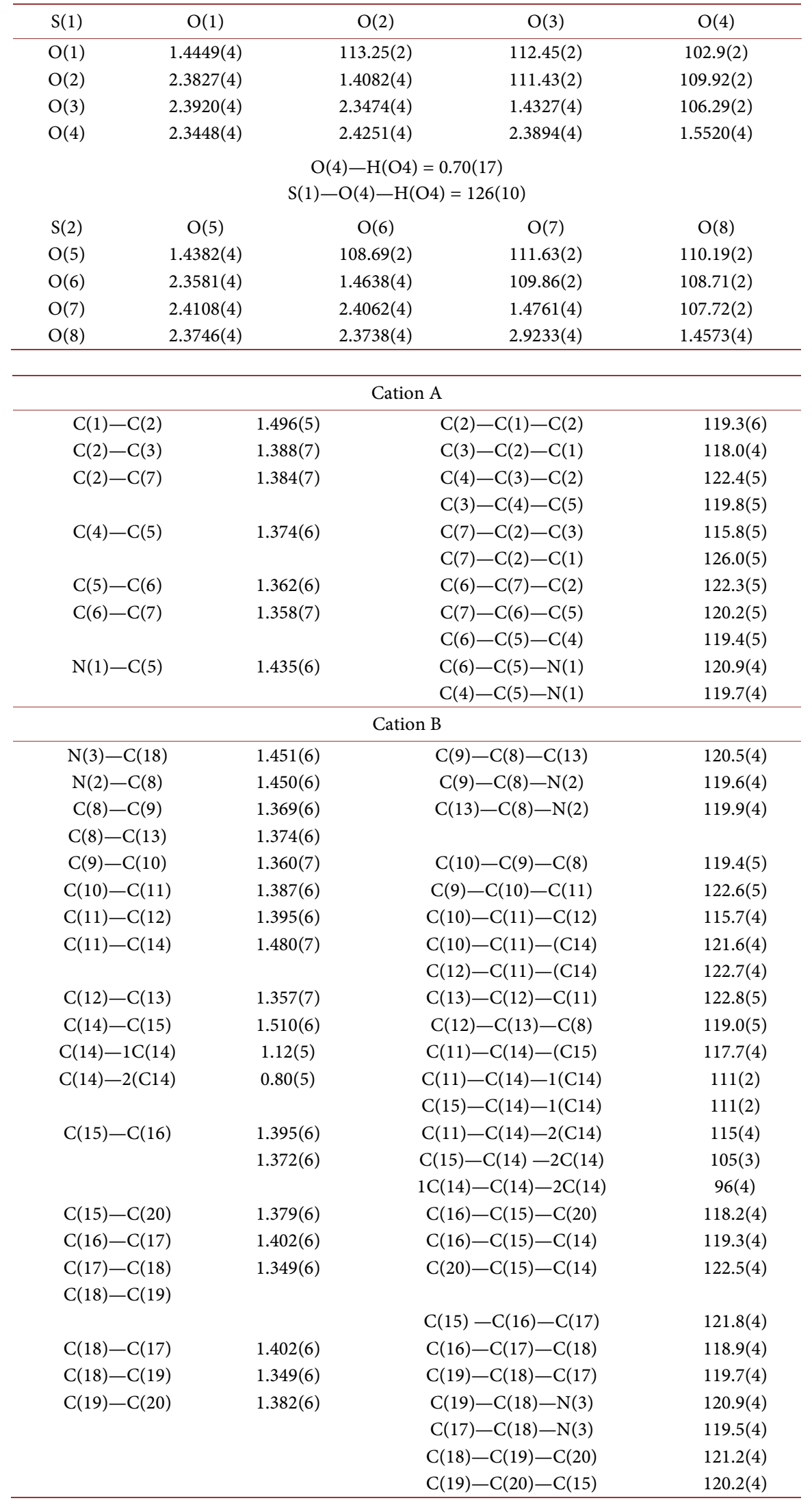




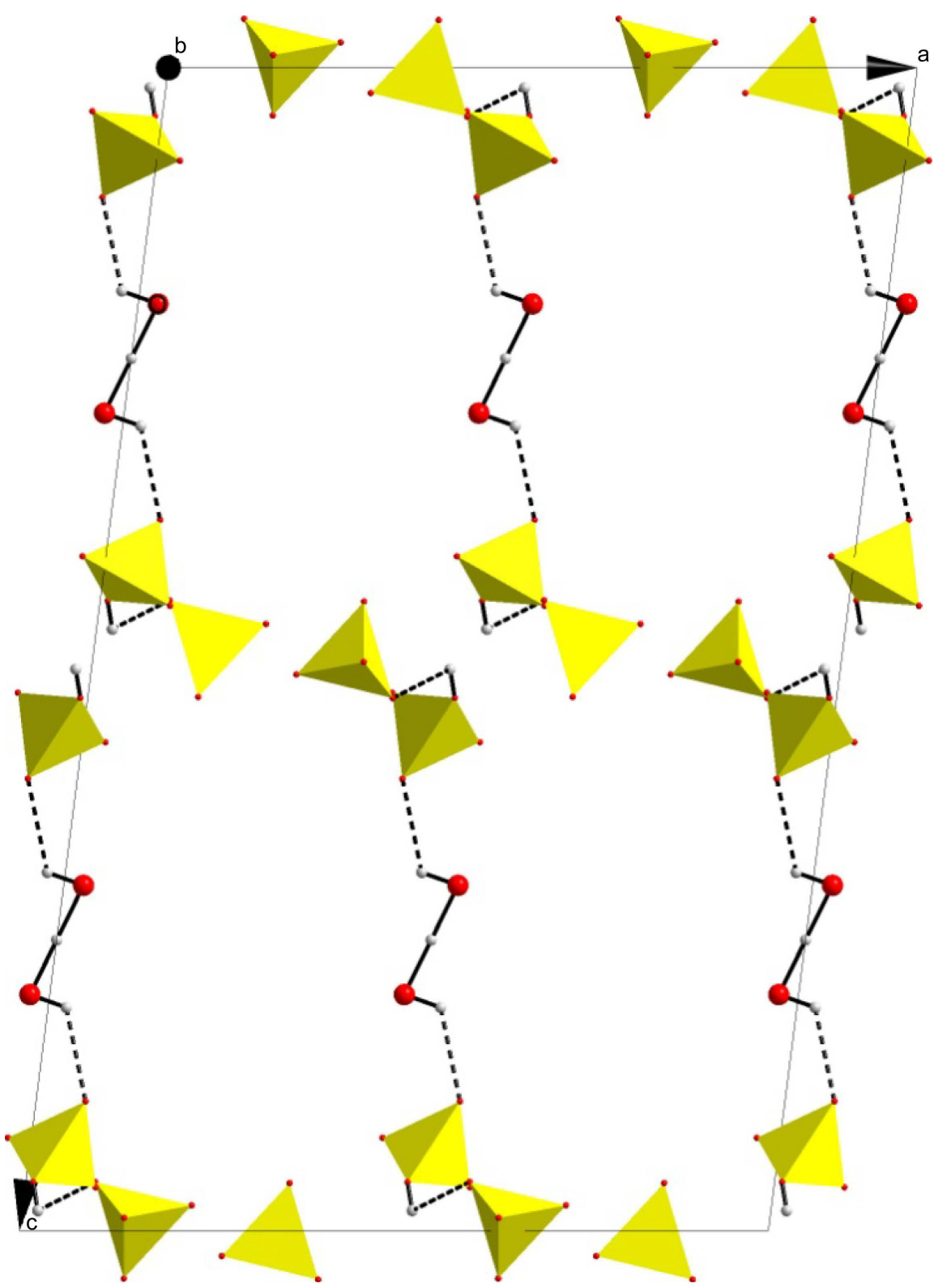

Figure 2. Projection along the $\boldsymbol{b}$ axis of the atomic arrangement in $\left(\mathrm{C}_{13} \mathrm{H}_{16} \mathrm{~N}_{2}\right)_{1.5}$ $\mathrm{HSO}_{4} \mathrm{SO}_{4} \cdot \mathrm{H}_{1.5} \mathrm{O}$.

dimensional network of structural units formed by clusters $\left[\mathrm{HS}_{2} \mathrm{O}_{8}\right]^{3-}$ sulfate, water molecules and organic cations. The mineral skeleton of this compound is formed by basic $\left[\mathrm{SO}_{4}\right]^{2-}$ and acidic $\left[\mathrm{HSO}_{4}\right]^{-}$groups which are interconnected via $\mathrm{O}(4)-\mathrm{H} \cdots \mathrm{O}(8)$ hydrogen bond leading to the formation of isolated clusters in the (a, b) plane. The same type of hydrogen bonds $\mathrm{O}-\mathrm{H}$... O links these mineral entities together, in pairs, via two water molecules which share a hydrogen atom located on a $C_{2}$ axis, to form a finite chains parallel to $c$ axis (Figure 3 ).

The short distance $\mathrm{O}(4) \cdots \mathrm{O}(8)=2.5151(6) \AA$, shows that this hydrogen bond was considered strong. Distances and bond angles describing the anions $\left[\mathrm{SO}_{4}\right]^{2-}$ and $\left[\mathrm{HSO}_{4}\right]^{-}$are illustrated in Table 2 . The lengths of $\mathrm{S}-\mathrm{O}$ bonds in are close to literature average [13] value of $1.4082(4) \AA . \mathrm{S}-\mathrm{O}(\mathrm{H})$ bond in is longer (1.5520(4) 


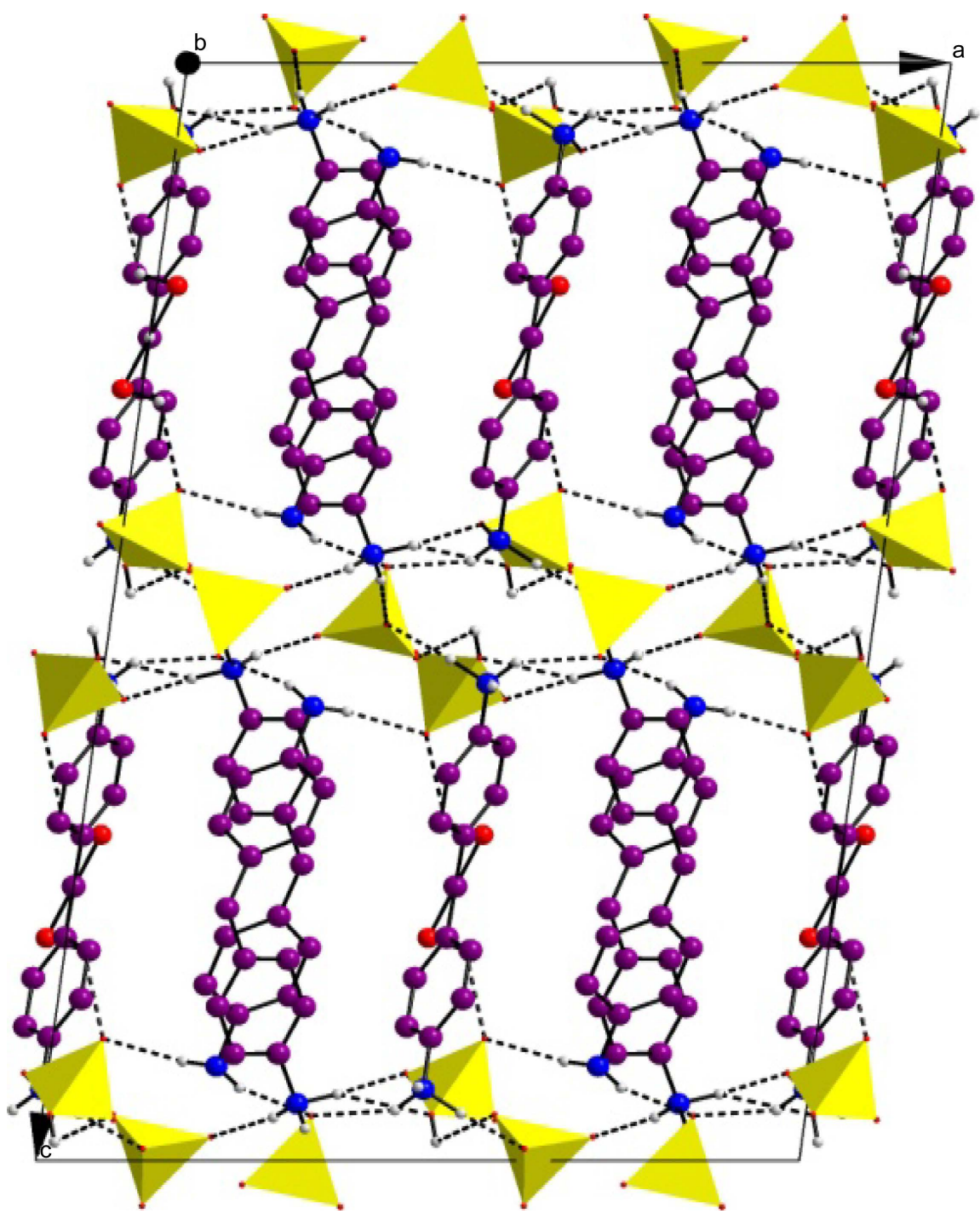

Figure 3. Projection along the $\boldsymbol{b}$ axis of the inorganic arrangement.

$\AA$ ), which is typical value, however, one of the remaining S-O bonds (S1-O4; $1,5520(4) \AA$ ), is slightly shorter than the others S1-O2 and S1-O3; this fact can be explained by the location of a proton on oxygen $\mathrm{O}(4)$ of the anion, this characteristic is in line with those observed in the protonated oxoanions [14] [15] [16]. The mean value of $\mathrm{S}-\mathrm{O}$ distances and angles $\mathrm{O}-\mathrm{S}-\mathrm{O}$ are: 1.459(4) $\AA$, $109.37(20)$ and 1.458(4) $\AA, 109.46(19)$ respectively for the tetrahedra S(1)O4 and $\mathrm{S}(2) \mathrm{O} 4$. These values are, also, in good agreement with those observed for similar anionic groups [17] [18]. The calculated average values of the distortion indices [19], corresponding to the different angles and distances in both $\mathrm{S}(1) \mathrm{O} 4$ and $\mathrm{S}(2) \mathrm{O} 4$ tetrahedron $[\mathrm{DI}(\mathrm{OSO})=0.0100-0.0316, \mathrm{DI}(\mathrm{SO})=0.0076-0.0291$ and $\mathrm{DI}(\mathrm{OO})=0.0602-0.0087]$ exhibit a pronounced distortion of the $\mathrm{O}-\mathrm{S}-\mathrm{O}$ angles compared to $\mathrm{S}-\mathrm{O}$ and $\mathrm{O} \cdots \mathrm{O}$ distances. So, each sulfate group can be considered as a rigid regular arrangement of oxygen atoms, with a displacement of the $\mathrm{S}$ atom from its centroid. The interaction of the sulfuric acid with the organic molecule $\left(\mathrm{C}_{13} \mathrm{H}_{14} \mathrm{~N}_{2}\right)$ leads to the protonation of the two nitrogen atoms of the 
4,4' diaminodiphenylmethan and the formation of two cations $\left(\mathrm{C}_{13} \mathrm{H}_{16} \mathrm{~N}_{2}\right)^{2+}$ cristallographically independent, respectively denoted: $\mathrm{A}\{\mathrm{C}(1) \mathrm{C}(7)\}$ and $\mathrm{B}\{\mathrm{C}(8)$ $\mathrm{C}(20)\}$.

Main geometrical characteristics of these cations are summarized in Table 2. With regards to the organic cations, the A cation has a local symmetry, in which the $\mathrm{C}(1)$ atom is located on a $C_{2}$ axis. Each sulfate anion is linked to its organic groups neighbors via $\mathrm{N}-\mathrm{H}$... O hydrogen bonds. Furthermore, the tetrahedron $\mathrm{HS}(1) \mathrm{O}_{4}$ is involving in an only one $\mathrm{O}-\mathrm{H} \cdots \mathrm{O}$ hydrogen bond with the water molecule and in four $\mathrm{N}-\mathrm{H}$... O hydrogen bond with three organic cations neighbors. The tetrahedron $\mathrm{S}(2) \mathrm{O}_{4}$ is engaged in six hydrogen bonds of the same type from six organic cations. Thus, hydrogen bonding plays a significant role in linking the organic molecules with the anionic sheets made by $\mathrm{HSO}_{4}$ and $\mathrm{SO}_{4}$ moieties. This interaction contributes to the cohesion and the stability of the structure. All the D (donor)-H...A (acceptor) hydrogen bonds are listed in $\mathrm{Ta}$ ble 3, with an upper limit of 2.458(7) $\AA$ for H...A distance and a lower limit of $87(12)^{\circ}$ for the $\mathrm{D}-\mathrm{H} \cdots \mathrm{A}$ bond angles. Consequently, this atomic arrangement exhibits two types of intermolecular interactions: $\mathrm{O}-\mathrm{H} \cdots \mathrm{O}$ and $\mathrm{N}-\mathrm{H} \cdots \mathrm{O}$, considered respectively as strong and weak hydrogen bonds. In this case, the titled compound contains two hydrogen bonds of the first type and ten of the second one. The $\mathrm{N}(1)-\mathrm{H}(1) \mathrm{N}(1) \cdots \mathrm{O}(7)$ interaction is considered as a strong hydrogen bond $[\mathrm{N}(1)-\mathrm{H}(1) \mathrm{N}(1) \cdots \mathrm{O}(7)=1.757(6) \AA][20]$. This latter provides the connection of the organic cations to the cluster $\left[\mathrm{H}_{2} \mathrm{~S}_{2} \mathrm{O}_{8}\right]^{2-}$. All these interactions play a fundamental role in the process of the creation and the stability of a three-dimensional framework of $\left(\mathrm{C}_{13} \mathrm{H}_{16} \mathrm{~N}_{2}\right)_{1.5} \mathrm{HSO}_{4} \mathrm{SO}_{4} \cdot \mathrm{H}_{1.5} \mathrm{O}$.

Table 3. Bond lengths $(\AA)$ and angles $\left(^{\circ}\right)$ in the Hydrogen-bonding scheme ${ }^{1}$ of $\left(\mathrm{C}_{13} \mathrm{H}_{16} \mathrm{~N}_{2}\right)_{1.5}$ $\mathrm{HSO}_{4} \mathrm{SO}_{4} \cdot \mathrm{H}_{1.5} \mathrm{O}$.

\begin{tabular}{ccccc}
\hline & $\mathrm{N}(\mathrm{O})-\mathrm{H}$ & $\mathrm{H} \cdots \mathrm{O}$ & $\mathrm{N}(\mathrm{O}) \cdots \mathrm{O}$ & $\mathrm{N}(\mathrm{O})-\mathrm{H} \cdots \mathrm{O}$ \\
\hline $\mathrm{N}(1)-\mathrm{H}(1) \mathrm{N}(1) \cdots \mathrm{O}(7)^{(\mathrm{i})}$ & 1.064 & $1.757(6)$ & $2.814(5)$ & $172(4)$ \\
$\mathrm{N}(1)-\mathrm{H}(2) \mathrm{N}(1) \cdots \mathrm{O}(5)^{(\mathrm{ii})}$ & 1.044 & $2.458(7)$ & $3.195(6)$ & $139(4)$ \\
$\mathrm{N}(1)-\mathrm{H}(3) \mathrm{N}(1) \cdots \mathrm{O}(1)^{(\mathrm{iii})}$ & 0.694 & $2.148(4)$ & $2.841(6)$ & $175(4)$ \\
$\mathrm{N}(2)-\mathrm{H}(1) \mathrm{N}(2) \cdots \mathrm{O}(6)^{(\mathrm{iv})}$ & 0.922 & $1.884(5)$ & $2.795(5)$ & $169(4)$ \\
$\mathrm{N}(2)-\mathrm{H}(2) \mathrm{N}(2) \cdots \mathrm{O}(3)^{(\mathrm{ii})}$ & 0.844 & $2.043(4)$ & $2.882(6)$ & $172(4)$ \\
$\mathrm{N}(2)-\mathrm{H}(3) \mathrm{N}(2) \cdots \mathrm{O}(5)$ & 0.891 & $2.004(5)$ & $2.857(6)$ & $160(4)$ \\
$\mathrm{N}(3)-\mathrm{H}(1) \mathrm{N}(3) \cdots \mathrm{O}(1)^{(\mathrm{v})}$ & 1.044 & $1.986(6)$ & $3.021(5)$ & $170(4)$ \\
$\mathrm{N}(3)-\mathrm{H}(1) \mathrm{N}(3) \cdots \mathrm{O}(4)^{(\mathrm{v})}$ & 1.045 & $2.4580(6)$ & $3.1945(6)$ & $127(4)$ \\
$\mathrm{N}(3)-\mathrm{H}(2) \mathrm{N}(3) \cdots \mathrm{O}(7)^{(\mathrm{ii})}$ & 0.929 & $1.880(4)$ & $2.796(6)$ & $169(1)$ \\
$\mathrm{N}(3)-\mathrm{H}(3) \mathrm{N}(3) \cdots \mathrm{O}(6)^{(\mathrm{vi})}$ & 0.774 & $2.032(4)$ & $2.787(6)$ & $165(4)$ \\
$\mathrm{O}\left(\mathrm{H}-\mathrm{H} 2 \mathrm{OW} \cdots \mathrm{O}(3)^{(\mathrm{vii})}\right.$ & 1.045 & $2.008(4)$ & $2.923(6)$ & $144(6)$ \\
$\mathrm{O}(4)-\mathrm{HO}(4) \cdots \mathrm{O}(8)^{(\mathrm{vi})}$ & 0.705 & $2.4410(2)$ & $2.5151(6)$ & $87(12)$
\end{tabular}

${ }^{1}$ Symmetrycode: $\mathrm{i}: \mathrm{x}-1 / 2,-\mathrm{y}+3 / 2, \mathrm{z}-1 / 2$; ii: $-\mathrm{x}+3 / 2, \mathrm{y}+1 / 2,-\mathrm{z}+3 / 2$; iii: $\mathrm{x}-1 / 2, \mathrm{y}+3 / 2$; $\mathrm{ziv}:-\mathrm{x}+3 / 2$, $-y+3 / 2,-z+2 ; \mathrm{v}: \mathrm{x}-1 / 2, \mathrm{y}+1 / 2, \mathrm{z}$ vi: $x,-y+1, z-1 / 2 ;$ vii: $x-1, y, z$. 


\subsection{IR Absorption Spectroscopy}

Recently, several researches on the vibrational properties of organic sulfates containing $\mathrm{HSO}_{4}$ and $\mathrm{SO}_{4}$ groups had been widely investigated [21] [22].

These studies have been focused, essentially, on the relationship between symmetry considerations and normalmodes vibrations of these groups. The common result is that these groups loose theirs free state symmetry $\left(\mathrm{T}_{\mathrm{d}}\right.$ for $\mathrm{SO}_{4}$ and $\mathrm{C}_{3 \mathrm{v}}$ for $\mathrm{HSO}_{4}$ ) to be $\mathrm{C}_{1}$ under the effect of its incorporation in the complex and its interaction with its crystalline environment. As a result, the vibrational properties are affected by moving the degeneracy of some normal modes, splitting of some IR active modes and appearance of some IR inactive modes. Here, we recall that the free ion $\mathrm{SO}_{4}$, in its ideal Td symmetry are $v_{1}=981 \mathrm{~cm}^{-1}, v_{2}=$ $451 \mathrm{~cm}^{-1}, v_{3}=1104 \mathrm{~cm}^{-1}$ and $v_{4}=614 \mathrm{~cm}^{-1}$ [23]. In this work, an attempt to assign frequencies to different stretching vibrations and deformation of the organic cation is performed based on previous work [24] [25]. A broad band extending from 3700 to $2500 \mathrm{~cm}^{-1}$ is observed in the IR spectrum (Figure 4). This broad band must be due to the symmetric and asymmetric stretching modes of $\mathrm{CH}, \mathrm{NH}_{3}, \mathrm{NH}_{2}, \mathrm{OH}, \mathrm{H}_{2} \mathrm{O}$ and $\mathrm{NH}_{3}$ bending and rocking may occur in the ranges $1640-1520$ and $933-722 \mathrm{~cm}^{-1}$. The out-of-plane $\mathrm{OH}$ bending mode $\mathrm{v}(\mathrm{OH})$ appears in infrared spectrum at the average 3744 to $3780 \mathrm{~cm}^{-1}$. The shifting of the stretching and bending vibrations of the $\mathrm{NH}_{3}$ group from the free state value confirms the formation of hydrogen bonds of varying strengths in the crystal. Frequencies in the range $933-722 \mathrm{~cm}^{-1}$ are attributed to $\rho(\mathrm{CH}), \rho\left(\mathrm{NH}_{3}\right)$, $\rho\left(\mathrm{NH}_{2}\right), \gamma(\mathrm{CH})$ and $\gamma(\mathrm{C}=\mathrm{C})$. The frequency bands in the region $410-484 \mathrm{~cm}^{-1}$ are attributed to the symmetric deformation vibration of $\delta \mathrm{s}\left(\mathrm{SO}_{4}\right)$. The asymmetric deformation symmetry $\delta \mathrm{as}\left(\mathrm{SO}_{4}\right)$ was observed in the area $602-671 \mathrm{~cm}^{-1}$.

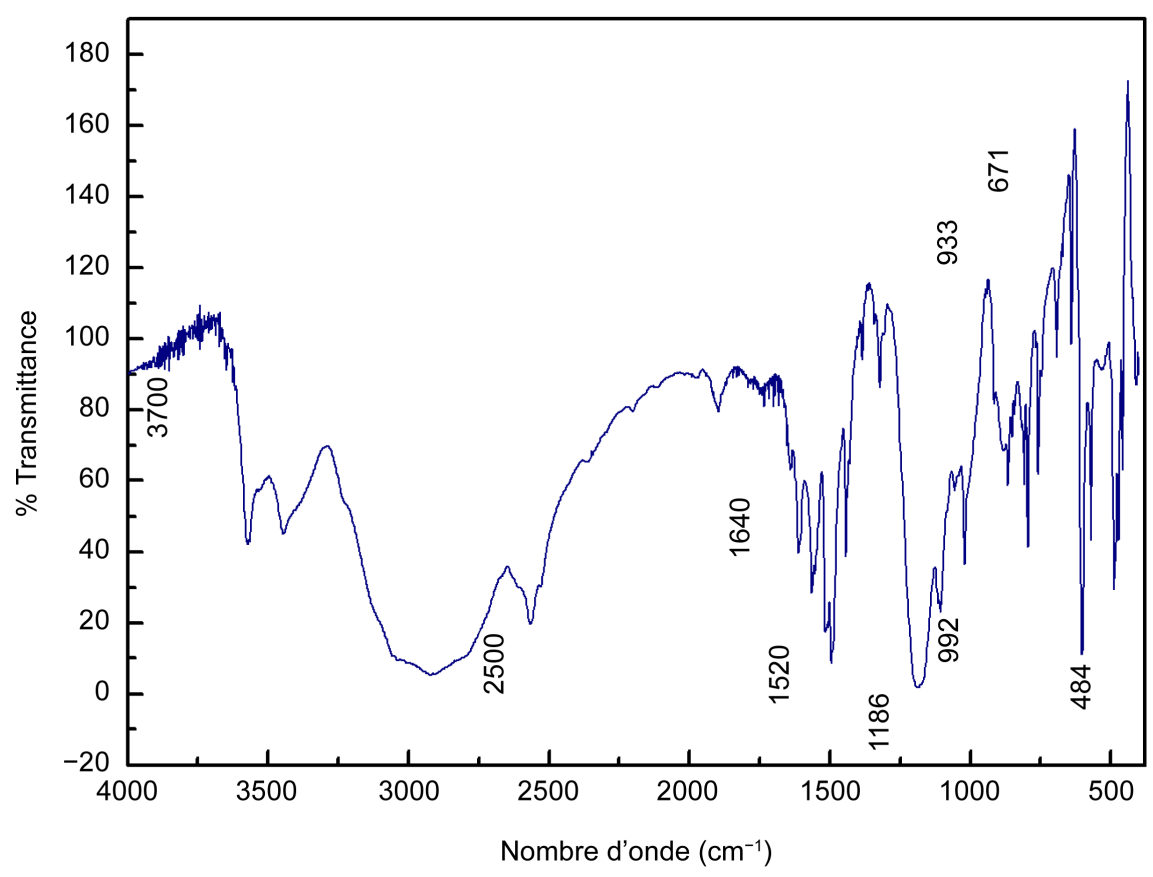

Figure 4. IR Spectrum of $\left(\mathrm{C}_{13} \mathrm{H}_{16} \mathrm{~N}_{2}\right)_{1.5} \mathrm{HSO}_{4} \mathrm{SO}_{4} \cdot \mathrm{H}_{1.5} \mathrm{O}$. 
While that connected to the symmetry of valence $\mathrm{SO}_{4}$ group is presented by the band $992 \mathrm{~cm}^{-1}$. Bands observed in the $992-1186 \mathrm{~cm}^{-1}$, on asymmetrical valence vibration $v \mathrm{~s}\left(\mathrm{SO}_{4}\right) \delta \mathrm{as}\left(\mathrm{SO}_{4}\right)$ region.

\subsection{Thermal Analysis}

The simultaneous TG-DTA analysis curves of $\left(\mathrm{C}_{13} \mathrm{H}_{16} \mathrm{~N}_{2}\right)_{1.5} \mathrm{HSO}_{4} \mathrm{SO}_{4} \cdot \mathrm{H}_{1.5} \mathrm{O}$ were carried out in air at a heating rate of $5^{\circ} \mathrm{C} / \mathrm{min}$ on a sample of $21.5 \mathrm{mg}$ placed in a platinum crucible and heated from ambient to $325^{\circ} \mathrm{C}$. The result obtained during the decomposition of the title compound is illustrated in Figure 5. This study shows that this complex is thermally stable up to $185^{\circ} \mathrm{C}$. The TGA curve revealed the presence of two steps weight losses. The first decomposition, from $185^{\circ} \mathrm{C}$ to $205^{\circ} \mathrm{C}$ which is accompanied by one shoulder on the DTA curve at $197^{\circ} \mathrm{C}$, corresponds to the loss of the water molecules (experimental weight loss: $3.72 \%$ and theoretical weight loss: $3.42 \%$ ) and leading to anhydrous framework of $\left(\mathrm{C}_{13} \mathrm{H}_{16} \mathrm{~N}_{2}\right)_{1.5} \mathrm{HSO}_{4} \mathrm{SO}_{4}$. The second stage, starts at about $220^{\circ} \mathrm{C}$ and ends above $300^{\circ} \mathrm{C}$, is assigned to the degradation of the organic entities (experimental loss: $65.46 \%$ and theoretical loss: $60.85 \%$ ). This phenomenon is accompanied by one endothermic peak observed on the DTA curve at about $238^{\circ} \mathrm{C}$.

\section{Conclusions}

The crystals of the 4,4'-diamoniumdiphenylmethan sulfate hydrate, $\left(\mathrm{C}_{13} \mathrm{H}_{16} \mathrm{~N}_{2}\right)_{1.5}$ $\mathrm{HSO}_{4} \mathrm{SO}_{4} \cdot \mathrm{H}_{1.5} \mathrm{O}$, have been synthesized by slow evaporation method at room temperature. The X-ray diffraction helped us to determine the cell parameters and the space group. The structural study showed that the anionic groups $\mathrm{SO}_{4}$ and $\mathrm{HSO}_{4}$ are gathered by inter-anionic strong hydrogen bonds giving birth to clusters

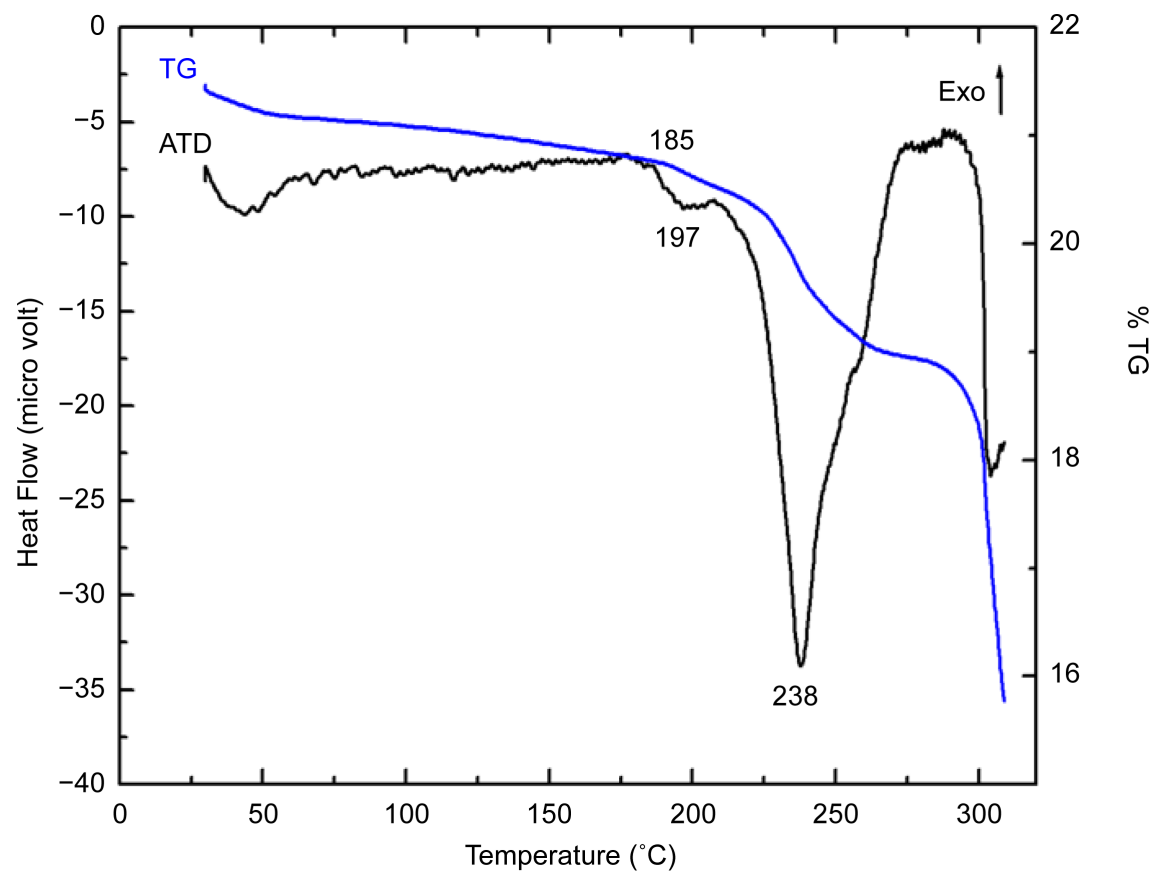

Figure 5. TG-DTA thermograms of $\left(\mathrm{C}_{13} \mathrm{H}_{16} \mathrm{~N}_{2}\right)_{1.5} \mathrm{HSO}_{4} \mathrm{SO}_{4} \cdot \mathrm{H}_{1.5} \mathrm{O}$. 
$\left[\mathrm{HS}_{2} \mathrm{O}_{8}\right]^{3-}$. It is also shown the scheme of hydrogen bonds connecting various organic cations with the sulfates clusters to yield a three-dimensional network.

The detailed vibrational spectral analysis, supported by an analysis using group theory, of the organic and the inorganic moieties was carried out leading to the counting and the allocation of frequencies characteristic of the compound.

The TG-DTA data allowed us to verify that the title salt is thermally stable up to $185^{\circ} \mathrm{C}$. The stability of the compound below this temperature can be explained by the different strong bonds observed by the X-ray diffraction. The thermal decomposition above $185^{\circ} \mathrm{C}$ takes place in two steps. The endothermic peaks at $197^{\circ} \mathrm{C}$ and $238^{\circ} \mathrm{C}$ are due to the thermal decomposition with release of the uncoordinated water and degradation of organic entities.

Moreover, a study of the electrical conductivity of the reported compound could open to it opportunities on applied plan.

\section{References}

[1] Reddy, A.L.M., Gowda, S.R., Shaijumon, M.M. and Ajayan, P.M. (2012) Hybrid Nanostructures for Energy Storage Applications. Advanced Materials, 24, 5045-5064. https://doi.org/10.1002/adma.201104502

[2] Sanchez, C., Belleville, P., Popall, M. and Nicole, L. (2011) Applications of Advanced Hybrid Organic-Inorganic Nanomaterials: From Laboratory to MArket. Chemical Society Reviews, 40, 696. https://doi.org/10.1039/c0cs00136h

[3] Dolbecq, A., Dumas, E., Mayer, C.R. and Mialane, P. (2010) Hybrid Organic, Inorganic Polyoxometalate Compounds: From Structural Diversity to Applications. Chemical Reviews, 110, 6009. https://doi.org/10.1021/cr1000578

[4] Hagrman, D., Hammond, R.P., Haushalter, R. and Zubieta, J. (1998) Organic/Inorganic Composite Materials: Hydrothermal Syntheses and Structures of the One- , Two- , and Three-Dimensional Copper(II) Sulfate-Organodiamine Phases [Cu$\left(\mathrm{H}_{2} \mathrm{O}\right)_{3}(4,4$-Bipyridine $\left.)\left(\mathrm{SO}_{4}\right)\right] \cdot 2 \mathrm{H}_{2} \mathrm{O}, \quad\left[\mathrm{Cu}(\text { bpe })_{2}\right]\left[\mathrm{Cu}(\right.$ bpe $\left.)\left(\mathrm{H}_{2} \mathrm{O}\right)_{2}\left(\mathrm{SO}_{4}\right)_{2}\right] \cdot 2 \mathrm{H}_{2} \mathrm{O}$, and $\left[\mathrm{Cu}(\mathrm{bpe})\left(\mathrm{H}_{2} \mathrm{O}\right)\left(\mathrm{SO}_{4}\right)\right]$ (bpe = Trans-1,2-Bis(4-Pyridyl)(Ethylene). Chemistry of Materials, 10, 2091-2100.

[5] Belhouchet, M., Savariault, J.M. and Mhiri, T. (2005) Crystal Structure and Thermal Behavior of Two New Organic Monosulfates $\mathrm{NH}_{3}\left(\mathrm{CH}_{2}\right)_{5} \mathrm{NH}_{3} \mathrm{SO}_{4} \cdot 1.5 \mathrm{H}_{2} \mathrm{O}$ and $\mathrm{NH}_{3}\left(\mathrm{CH}_{2}\right)_{9} \mathrm{NH}_{3} \mathrm{SO}_{4} \cdot \mathrm{H}_{2} \mathrm{O}$. Journal of Physics and Chemistry of Solids, 66, 1294 1301. https://doi.org/10.1016/j.jpcs.2005.04.010

[6] Finn, R.C., Zubieta, J. and Haushalter, R.C. (2003) Crystal Chemistry of Organically Templated Vanadium Phosphates and Organophosphonates. Progress in Inorganic Chemistry, 51, 451. https://doi.org/10.1002/chin.200315296

[7] Koo, B., Ollette, W., Burkholder, E.M., Golub, V., O'connor, C.J. and Zubieta, J. (2004) Hydrothermal Synthesis and Structural Characterization of OrganicallyTemplated Copper Vanadium Phosphates: The Two-Dimensional [ $\left\{\mathrm{Cu}_{2}\right.$-(bis-terpy) $\left.\}-\mathrm{V}_{3} \mathrm{O}_{5}\left(\mathrm{HPO}_{4}\right)_{2}\left(\mathrm{PO}_{4}\right)\right]$ (1) and the Three-Dimensional $\left[\left\{\mathrm{Cu}_{2}(\right.\right.$ bisterpy $\left.)\right\} \mathrm{V}_{2} \mathrm{O}_{5}$ $\left(\mathrm{HPO}_{4}\right)_{2}$ ] (2) (Bisterpy=2,2':4',4': 2',2'” Quarterpyridyl, 6',6”-Dipyridine). Solid State Sciences, 6, 461-468.

[8] Allouch, F., Zouari, F., Chabchoub, F. and Salem, M. (2008) 5-Amino-3-Methyl-1Phenyl-1H-1,2,4-Triazole. Acta Crystallographica E, 64, 684. https://doi.org/10.1107/S1600536808005801

[9] Belghith, S., Chmengui, S. and Hamada, L.B. (2015) Crystal Structure and Physicochemical Properties of a New Tris (2-Amoniumbenzamide) Sulfate $\left(\mathrm{C}_{7} \mathrm{H}_{9} \mathrm{~N}_{2} \mathrm{O}\right)_{3} \mathrm{HS}$ - 
$\mathrm{O}_{4} \mathrm{SO}_{4}$. Open Journal of Inorganic Chemistry, 5, 112-121.

[10] Pecaut, J., Le Fur, Y. and Masse, R. (1993) Crystal Engineering and Structural Investigations of the 2-Amino-5-Nitropyridinium Salts $\mathrm{C}_{5} \mathrm{H}_{6} \mathrm{~N}_{3} \mathrm{O}_{2}^{+} \cdot \mathrm{HSO}_{4}^{-}$and $\mathrm{C}_{5-} \mathrm{H}_{6} \mathrm{~N}_{3} \mathrm{O}_{2}^{+} \cdot \mathrm{H}_{2} \mathrm{AsO}_{4}^{-}$. Acta Crystallographica B, 49, 535. https://doi.org/10.1107/S0108768192011431

[11] Chen, R.H., Li, M.W. and Yang, S.C. (1992) X-Ray Study on the Phase Transitions in Triammonium Hydrogen Disulfate Crystals and Deuterated Crystals. Phase Transitions: A Multinational Journal, 37, 141-147.

[12] Sheldrick, G.M. (1997) SHELX-97. University of Göttingen, Göttingen.

[13] Saïd, S., Elleuch, S., Slepokura, K., Lis, T. and Naïli, H. (2016) Crystal Structure, Thermal Analysis and IR Spectrometric Investigation of the Tris (2,6-DiaminopyRidinium) Hydrogen Sulfate Sulfate Monohydrate. Journal of Molecular Structure, 1114, 189-196. https://doi.org/10.1016/j.molstruc.2016.02.050

[14] Ferraris, G. and Ivaldi, G. (1984) X-OH and O-HO Bond Lengths in Protonated Oxoanions. Acta Crystallographica B, 40, 1.

[15] Xu, Y.M., Gao, S. and Ng, S.W. (2009) Bis(4-HydroxyPyridinium) Sulfate Monohydrate. Acta Crystallographica E, 65, 3146. https://doi.org/10.1107/S1600536809048521

[16] Xu, Y.M., Gao, S. and Ng, S.W. (2009) Tris(4-Hydroxypyridinium) Hydrogen Sulfate-Sulfate Monohydrate. Acta Crystallographica E, 65, 3147.

[17] Mostad, A. and Natarajan, S. (1996) Crystal Structure of an Adduct of Sarcosine with Sulfuric Acid (at 140 K). Crystal Research and Technology, 31, 295-300.

[18] Sahbani, T., Smirani, W., Al-Deyab, S. and Rzaigui, M. (2012) Synthesis and Characterization of a New Organic Sulphate [2,3- $\left.\left(\mathrm{CH}_{3}\right)_{2} \mathrm{C}_{6} \mathrm{H}_{3} \mathrm{NH}_{3}\right] \mathrm{HSO}_{4} \cdot \mathrm{H}_{2} \mathrm{O}$. Materials Research Bulletin, 47, 1455-1458. https://doi.org/10.1016/j.materresbull.2012.02.041

[19] Brown, I.D. (1976) On the Geometry of O-HO Hydrogen Bonds. Acta Crystallographica A, 32, 24-31. https://doi.org/10.1107/S0567739476000041

[20] Abadi, B.E.A., Moss, D.S. and Palmer, R.A. (1984) Molecular Structure of an Ancient Folk Medicine: Berberine Hydrogen Sulfate. Journal of Crystallographic and Spectroscopic Research, 14, 269-281.

[21] Mauro, C. and Ribeiro, C. (2012) High Viscosity of Imidazolium Ionic Liquids with the Hydrogen Sulfate Anion: A Raman Spectroscopy Study. The Journal of Physical Chemistry B, 116, 7281 .

[22] Boer, G.J., Sokolik, I.N. and Martin, S.T. (2007) Infrared Optical Constants of Aqueous Sulfate-Nitrate-Ammonium Multi-Component Tropospheric Aerosols from Attenuated Total Reflectance Measurements-Part I: Results and Analysis of Spectral Absorbing Features. Journal of Quantitative Spectroscopy and Radiative Transfer, 108, 17. https://doi.org/10.1016/j.jqsrt.2007.02.017

[23] Hertzberg, G. (1966) Infrared and Raman Spectra of Polyatomic Molecules. Van Nostrand, New York.

[24] Wang, A., Freeman, J.J., Jolliff, B.L. and Chou, I.M. (2006) Sulfates on Mars: A Systematic Raman Spectroscopic Study of Hydration States of Magnesium Sulfates. Geochimica et Cosmochimica Acta, 70, 6118. https://doi.org/10.1016/j.gca.2006.05.022

[25] Guerfel, T. and Jouini, A. (2011) Crystal Structure, Thermal Analysis and IR Spectroscopic Investigation of Bis (N-Methyl Anilinium) Sulfate. Open Journal of Inorganic Chemistry, 1, 47-53. https://doi.org/10.4236/ojic.2011.13007 


\section{Appendix A. Supplementary Data}

The final atomic coordinate and thermal parameters are given in Table S1. Those of hydrogen-atoms were also determined but are not given, in order to shorten the table.

Table S1. The final atomic coordinates and equivalent temperature factors for $\left(\mathrm{C}_{13} \mathrm{H}_{16} \mathrm{~N}_{2}\right)_{1.5} \mathrm{HSO}_{4} \mathrm{SO}_{4} \cdot \mathrm{H}_{1.5} \mathrm{O}$.

\begin{tabular}{|c|c|c|c|c|}
\hline Atom & $\mathrm{X}(\sigma)$ & $\mathrm{Y}(\sigma)$ & $\mathrm{Z}(\sigma)$ & Ueq $\left(\AA^{2}\right)$ \\
\hline $\mathrm{S}(1)$ & $0.96253(6)$ & $0.06080(11)$ & $0.56840(4)$ & $0.0344(4)$ \\
\hline$S(2)$ & $0.84920(5)$ & $0.52069(10)$ & $1.00769(4)$ & $0.0283(4)$ \\
\hline $\mathrm{O}(1)$ & $1.03122(15)$ & $-0.0216(3)$ & $0.57994(12)$ & $0.0434(9)$ \\
\hline $\mathrm{O}(2)$ & $0.90586(18)$ & $-0.0113(4)$ & $0.53733(14)$ & $0.0689(11)$ \\
\hline $\mathrm{O}(3)$ & $0.93390(17)$ & $0.1135(3)$ & $0.61125(12)$ & $0.0524(9)$ \\
\hline $\mathrm{O}(4)$ & $0.9901(2)$ & $0.1931(3)$ & $0.54180(16)$ & $0.0618(11)$ \\
\hline $\mathrm{O}(5)$ & $0.85254(17)$ & $0.5729(3)$ & $0.95896(11)$ & $0.0488(9)$ \\
\hline $\mathrm{O}(6)$ & $0.77454(16)$ & $0.5547(3)$ & $1.02175(12)$ & $0.0454(9)$ \\
\hline $\mathrm{O}(7)$ & $0.86231(16)$ & $0.3654(3)$ & $1.01099(11)$ & $0.0442(9)$ \\
\hline $\mathrm{O}(8)$ & $0.90720(17)$ & $0.5895(3)$ & $1.04201(12)$ & $0.0556(10)$ \\
\hline $\mathrm{N}(1)$ & $0.5054(3)$ & $1.1817(6)$ & $0.56520(16)$ & $0.0349(12)$ \\
\hline $\mathrm{N}(2)$ & $0.7194(3)$ & $0.7146(5)$ & $0.91374(16)$ & $0.0340(10)$ \\
\hline $\mathrm{N}(3)$ & $0.6685(3)$ & $0.6334(5)$ & $0.55215(16)$ & $0.0328(10)$ \\
\hline $\mathrm{C}(1)$ & 0.5000 & $0.9100(7)$ & 0.75000 & $0.0437(18)$ \\
\hline$C(2)$ & $0.5022(2)$ & $0.9906(4)$ & $0.70337(16)$ & $0.0317(11)$ \\
\hline$C(3)$ & $0.5366(3)$ & $0.9261(6)$ & $0.66661(19)$ & $0.0383(13)$ \\
\hline $\mathrm{C}(4)$ & $0.5383(2)$ & $0.9876(5)$ & $0.6223(2)$ & $0.0336(12)$ \\
\hline$C(5)$ & $0.5051(2)$ & $1.1185(4)$ & $0.61256(15)$ & $0.0280(11)$ \\
\hline$C(6)$ & $0.4700(3)$ & $1.1843(6)$ & $0.64757(18)$ & $0.0406(13)$ \\
\hline$C(7)$ & $0.4686(3)$ & $1.1215(5)$ & $0.6918(2)$ & $0.0439(14)$ \\
\hline$C(8)$ & $0.7374(2)$ & $0.7624(4)$ & $0.86656(15)$ & $0.0310(11)$ \\
\hline $\mathrm{C}(9)$ & $0.8020(3)$ & $0.7143(5)$ & $0.84970(18)$ & $0.0424(12)$ \\
\hline$C(10)$ & $0.8195(3)$ & $0.7618(5)$ & $0.80590(18)$ & $0.0435(13)$ \\
\hline$C(11)$ & $0.7741(2)$ & $0.8577(4)$ & $0.77711(16)$ & $0.0347(11)$ \\
\hline$C(12)$ & $0.7085(3)$ & $0.9018(5)$ & $0.7957(2)$ & $0.0470(14)$ \\
\hline$C(13)$ & $0.6903(3)$ & $0.8574(5)$ & $0.83955(19)$ & $0.0424(13)$ \\
\hline$C(14)$ & $0.7949(3)$ & $0.9094(7)$ & $0.72988(18)$ & $0.0466(14)$ \\
\hline$C(15)$ & $0.7634(2)$ & $0.8299(4)$ & $0.68415(15)$ & $0.0309(11)$ \\
\hline$C(16)$ & $0.7894(3)$ & $0.8622(5)$ & $0.64072(17)$ & $0.0365(11)$ \\
\hline$C(17)$ & $0.7606(2)$ & $0.7969(4)$ & $0.59745(19)$ & $0.0367(12)$ \\
\hline$C(18)$ & $0.7017(2)$ & $0.6976(4)$ & $0.59778(15)$ & $0.0288(11)$ \\
\hline$C(19)$ & $0.6766(3)$ & $0.6634(5)$ & $0.64043(17)$ & $0.0347(12)$ \\
\hline$C(20)$ & $0.7059(2)$ & $0.7285(4)$ & $0.68375(17)$ & $0.0351(11)$ \\
\hline
\end{tabular}


Submit or recommend next manuscript to SCIRP and we will provide best service for you:

Accepting pre-submission inquiries through Email, Facebook, LinkedIn, Twitter, etc. A wide selection of journals (inclusive of 9 subjects, more than 200 journals)

Providing 24-hour high-quality service

User-friendly online submission system

Fair and swift peer-review system

Efficient typesetting and proofreading procedure

Display of the result of downloads and visits, as well as the number of cited articles Maximum dissemination of your research work

Submit your manuscript at: http://papersubmission.scirp.org/

Or contact ojic@scirp.org 